\title{
Initial Building Investigations at Aberdeen Proving Ground, Maryland: Building E5190
}

by K.L. Brubaker, J.M. Dougherty, and C. Tome

Reclamation Engineering and Geosciences Section, Energy Systems Division, Argonne National Laboratory, 9700 South Cass Avenue, Argonne, Illinois 60439

October 1993

Work sponsored by United States Department of Defense, United States Army, Aberdeen Proving Ground, Maryland 
This document is printed on recycled paper. 


\section{Contents}

Abstract

1 Introduction

1.1 Background.

1.2 Initial Building Investigation Objectives

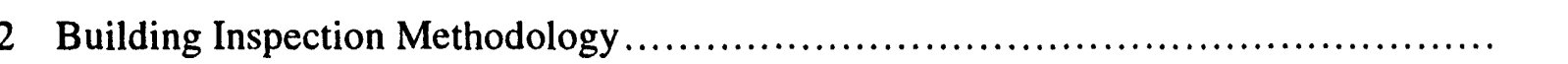

3 Summary of Historical Records Search for Building E5190................... 8

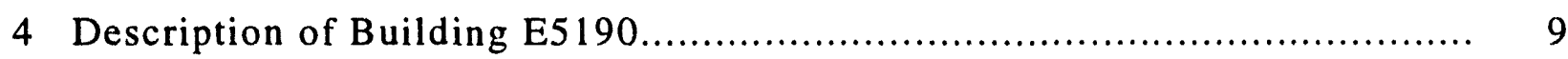

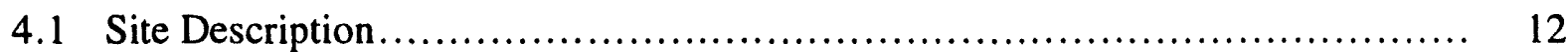

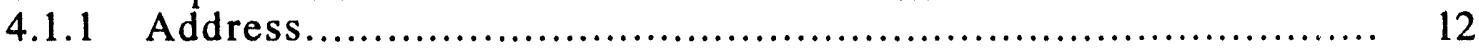

4.1.2 Proximity to Other Buildings......................................... 12

4.1.3 Exterior Footprint Dimensions ........................................ 12

4.1.4 Surface Soils and Topographical Conditions ......................... 12

4.1.5 Vegetation in the Immediate Vicinity ................................... 13

4.1.6 External Aboveground Structures or Equipment ...................... 13

4.1.7 Connections with Adjacent Buildings .................................. 13

4.1.8 Location and Type of Underground Structures........................ 13

4.1.9 Location and Type of Surface Drainage System ........................ 14

4.1.10 Utility Access Points and Utility Type................................. 14

4.1.11 Piping Exiting the Building and Entering the Ground ................. 14

4.1.12 Location and Direction of Nearby Roads and Sidewalks .............. 14

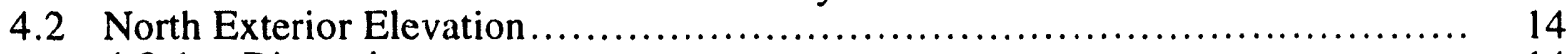

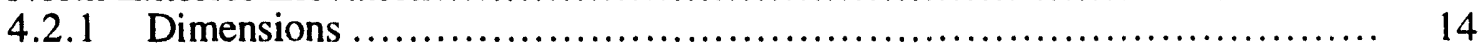

4.2.2 Construction Materials ..................................................... 14

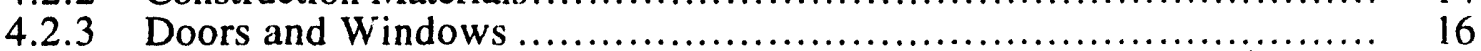

4.2.4 Piping along or Connected with this Face of the Building ............. 16

4.2.5 Utility Connections...................................................... 16

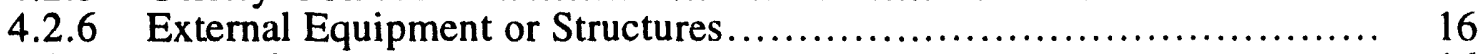

4.2.7 Vegetation.............................................................. 16

4.2 .8 Overall Condition ...................................................... 16

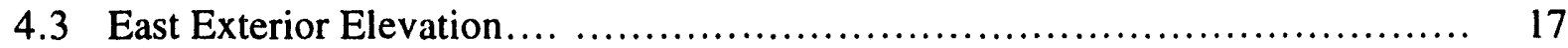

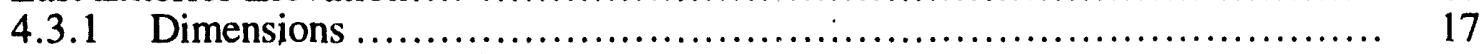

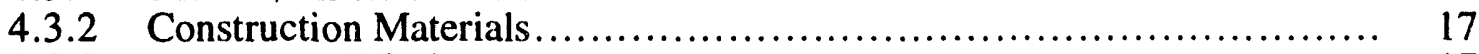

4.3 .3 Doors and Windows .............................................. 17

4.3.4 Piping along or Connected with this Building Elevation.............. 17

4.3.5 Utility Connections................................................. 17

4.3.6 External Equipment or Structures................................... 19

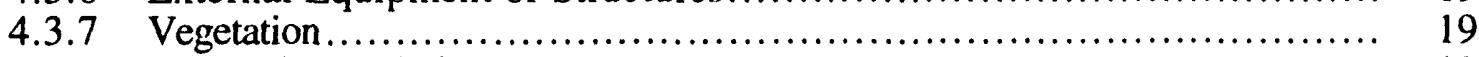

4.3.8 Overall Condition.................................................... 19

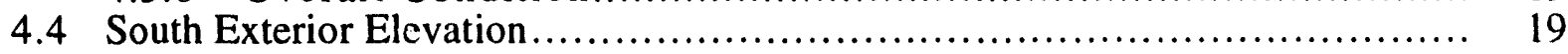

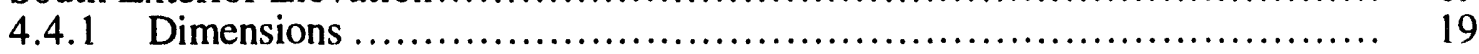

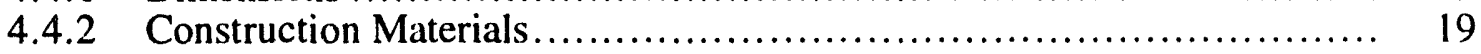

4.4.3 Doors and Windows ............................................. 19

4.4.4 Piping along or Connected with this Face of the Building ............ 21

4.4.5 Utility Connections................................................ 21

4.4.6 External Equipment or Structures................................... 21 


\section{Contents (Cont.)}

4.4 .7 Vegetation ......................................................... 21

4.4.8 Overall Condition................................................................ 21

4.5 West Exterior Elevation ................................................... 21

4.5.1 Dimensions .......................................................... 21

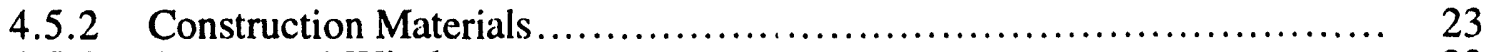

4.5.3 Doors and Windows .......................................... 23

4.5.4 Piping along or Connected with this Face of the Building ........... 23

4.5.5 Utility Connections................................................... 23

4.5.6 External Equipment or Structures................................ 23

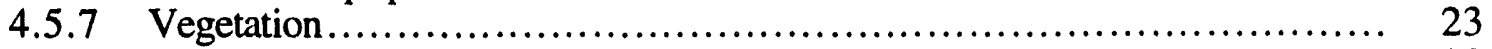

4.5.8 Overall Condition..................................................... 23

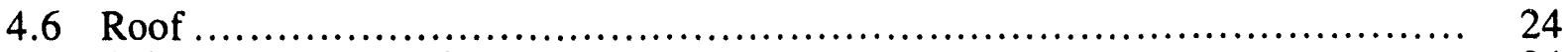

4.6.1 Type and Dimensions ................................................ 24

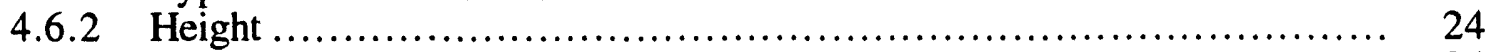

4.6 .3 Surface Materials ................................................. 24

4.6.4 Structural Materials Used in Roof-Support Systemi................... 24

4.6.5 Condition ........................................................... 24

4.6.6 Equipment Located at, on, or in the Roof............................. 24

4.6.7 Chimneys, Roof Vents, or Vent Stacks ......................... 25

4.6.8 Present Piping and Evidence of Former Piping Located
on the Roof................................................................. 25

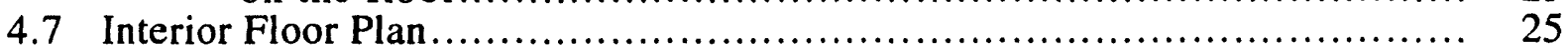

4.7.1 Interior Room Number and Dimensions ............................. 25

4.7.2 Room Perimeter Walls ......................................... 25

4.7.3 Floor Construction Materials, Condition, and Configuration............ 25

4.7.4 Floor Penetrations ................................................ 31

4.7.5 Location and Size of Interior Partitions ............................ 31

4.7.6 Equipment or Supplies Present....................................... 31

4.8 North Interior Elevation...................................................... 32

4.8.1 Wall Characteristics ............................................... 32

4.8.2 Interior Wall Finish Materials .................................... 32

4.8.3 Piping Attached to or Associated with the Wall ......................... 32

4.8.4 Equipment Connected with this Elevation.............................. 32

4.8.5 Doors and Windows ............................................ 33

4.9 East Interior Elevation.................................................... 33

4.9 .1 Wall Characteristics ............................................... 33

4.9.2 Interior Wall Finish Materials ...................................... 33

4.9.3 Piping Attached to or Associated with the Wall ........................... 33

4.9.4 Equipment Connected with this Elevation................................ 33

4.9.5 Doors and Windows ................................................... 34

4.10 South Interior Elevation.......................................................... 34

4.10.1 Wall Characteristics ............................................... 34

4.10 .2 Interic r Wall Finish Materials .............................................. 34

4.10.3 Piping Attached to or Associated with the Wall ..................... 34

4.10.4 Equiprnent Connected with this Elevation.............................. 34

4.10 .5 Doors and Windows ............................................. 34

4.11 West Interior Elevation...................................................... 35

4.11.1 Wall Characteristics ....................................................... 35

4.11 .2 Interior Wall Finish Material............................................... 35

4.11.3 Piping Attached to or Associated with the Wall ......................... 35 


\section{Contents (Cont.)}

4.11.4 Equipment Connected with this Elevati:nn........................... 35

4.11.5 Doors and Windows ............................................... 35

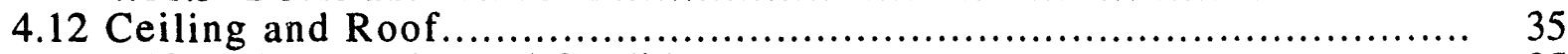

4.12.1 Construction and Condition ........................................ 35

4.12.2 Piping and Equipment............................................ 36

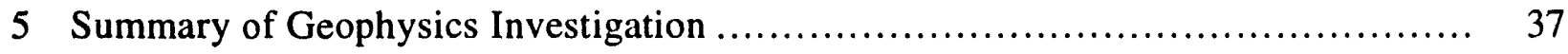

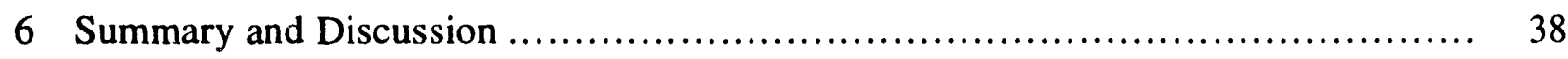

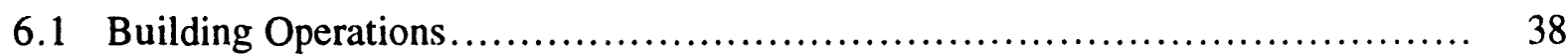

6.2 Summary of Potentially Contaminated Compartments ...................... 38

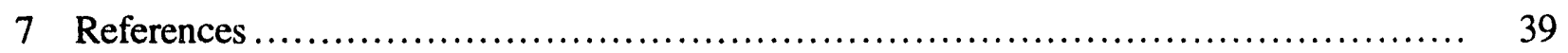

\section{Figures}

1 Map Showing the Location of Aberdeen Proving Ground ....................... 2

2 Decommissioning Process for Buildings at Aberdeen

Proving Ground.....

3 General Site Map of Aberdeen Proving Ground in the Vicinity of Building E5190....

4 Building E5190 Site Plan...

5 Building E5190 North Exterior Elevation

6 Building E5190 East Exterior Elevation.

7 Building E5190 South Exterior Elevation

8 Building E5190 West Exterior Elevation.

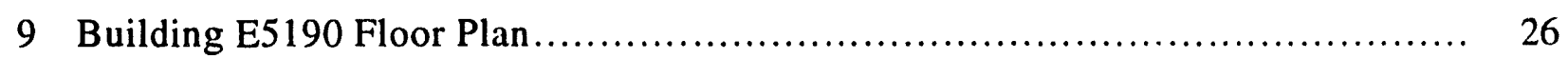

10 Building E5190 North Interior Elevation ................................ 27

11 Building E5190 East Interior Elevation ................................. 28

12 Building E5190 South Interior Wall ...................................... 29

13 Building E5190 West Interior Wall ..................................... 30 


\title{
Initial Building Investigations at Aberdeen Proving Ground, Maryland: Building E5190
}

by

K.L. Brubaker, J.M. Dougherty, and C. Tome

\begin{abstract}
As part of a building decommissioning and demolition program at Aberdeen Proving Ground, a detailed inspection of each target building is conducted in order to characterize and describe the state of the building as it currently exists and to identify areas potentially contaminated with toxic or other hazardous substances. Room surfaces, drains and sumps, remaining equipment, and such associated exterior aboveground and underground appurtenances as tanks and pipelines are among the features, generically termed compartments, that may be potentially contaminated. Detailed drawings are prepared to illustrate the existing structure of each building. This report presents the results of the inspection of building E5190 in the Edgewood/Canal Creek area of Aberdeen Proving Ground. This building houses a 10,000-gal tank formerly used to store xylene. Eleven potentially contaminated compartments were identified in this building and its vicinity.
\end{abstract}

\section{Introduction}

\subsection{Background}

The U.S. Army's Aberdeen Proving Ground (APG) is located on Chesapeake Bay in Harford and Baltimore counties, Maryland, arid occupies a total area of approximately 30,000 acres. Figure 1 shows the location of APG and its subdivision into the Edgewood and Aberdeen areas. The primary mission at APG is the testing and evaluation of U.S. Army materiel, and since its beginning in 1917, the Edgewood area of APG has been the principal location for chemical-warfare-agent research, development, and testing in the United States. During the two world wars, Aberdeen Proving Ground was also the location of facilities for the production of chemical-warfare agents and has been a center for the storage of chemical-warfare materiel (Nemeth 1989).

Many buildings constructed between 1917 and the 1950s are no longer used because of obsolescence and their poor state of repair, and APG desires to decommission and demolish 


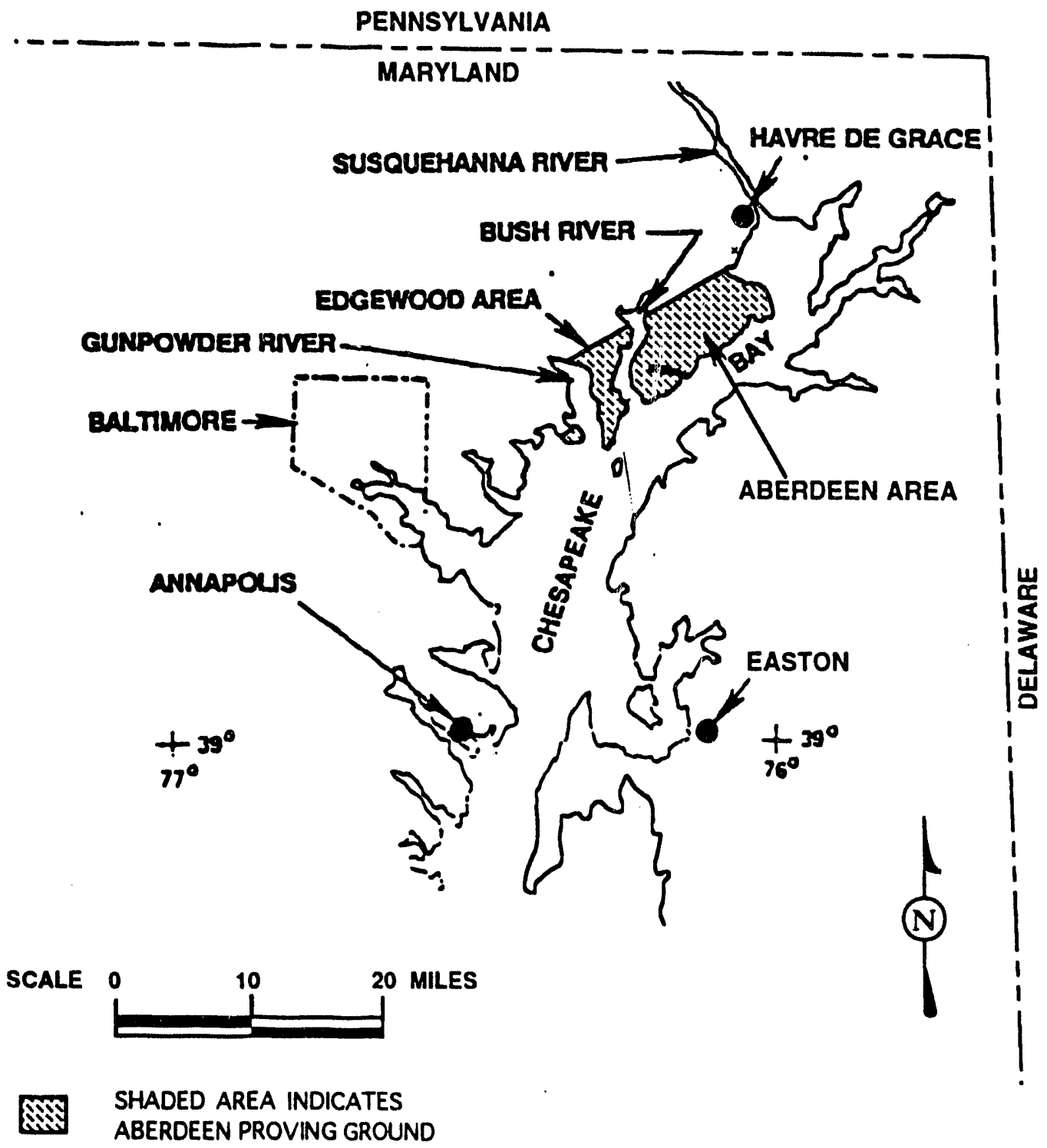

FIGURE 1 Map Showing the Location of Aberdeen Proving Ground

approximately 30 of these buildings. Because most were used for research, development, testing, and pilot-scale production testing of chemical-warfare agents and other military-unique substances (such as incendiary materials and munitions containing these materials), the potential exists for parts of these buildings to be contaminated with such substances, their degradation products, and other laboratory or industrial chemicals. These buildings, together with associated external structures or appurtenances (including underground or aboveground storage tanks, pipelines, and outbuildings), may contribute to existing environmental problems at APG. Uncontrolled releases of toxic materials during their decommissioning and demolition may constitute an additional threat to human health and safety. 
Aberdeen Proving Ground has commissioned Argonne National Laboratory (ANL) to carry out a program to address these concerns. Argonne's approach to the problem consists of a multiphase program of investigation for each individual building, which includes an initial building evaluation phase, one or more sampling and analysis phases, and a final demolition-planning phase. A preliminary risk assessment for the demolition is prepared in phase one. As subsequent phases are executed, this risk assessment is updated, so that after the investigation is completed, a final building-demolition risk assessment is available for use in demolition planning and execution. Figure 2 shows this process in flowchart form.

This report presents the results from the initial inspection of Building E5190 (formerly 90A) that was conducted on May 5, 1992, by the ANL inspection team. Concurrently, a separate team of ANL geophysicists conducted a geophysical survey of the area surrounding Building E5190.

\subsection{Initial Building Investigation Objectives}

The principal objective of the initial investigation is to obtain the information necessary for the development of a field sampling plan (FSP) for the building and for the development of the preliminary risk assessment. One secondary objective is to gather information about the structure that will be required in planning the eventual demolition. Another secondary objective is to use the information gathered during the building inspection to assist the Army in complying with the requirements of the National Historic Preservation Act (1966), as amended, and its associated regulations.

More specifically, the objectives of the building inspection, including the geophysical study, are as follows:

1. To identify all potential "compartments" in which contaminants of concern may be present;

2. To document the location, dimensions, physical condition, accessibility, and any other relevant attributes of each compartment;

3. To collect information about the design and construction of the building that is needed for the final demolition plan;

4. To locate, identify, and obtain copies of historical records that provide additional information regarding the location of potential contamination within and near the building and information pertaining to the design and construction of the building and its support systems (heating, ventilation, and air conditioning [HVAC]; sewage; electrical power; water; and other specialized systems, such as steam, compressed gas, etc.); and 


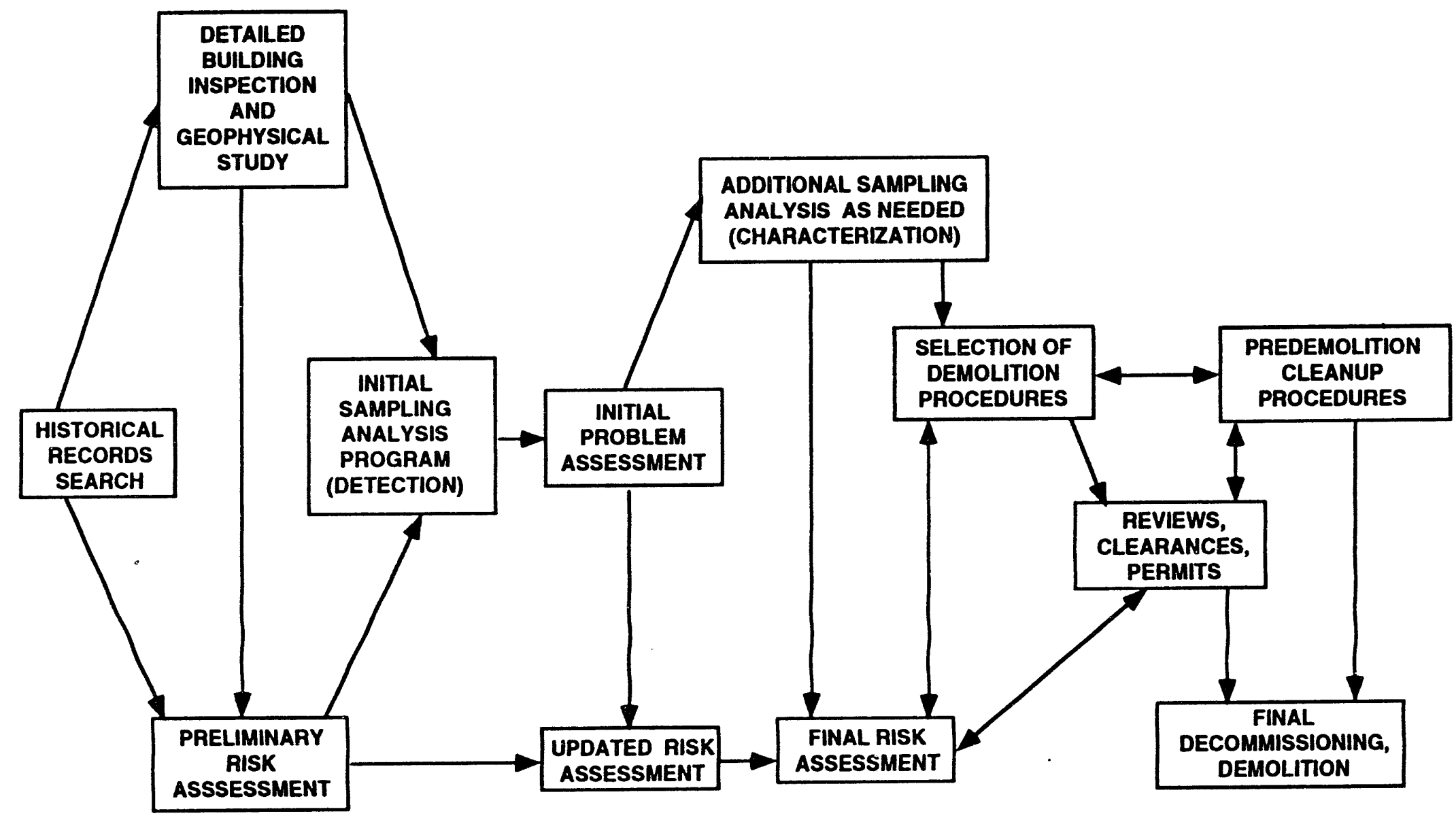

FIGURE 2 Decommissioning Process for Buildings at Aberdeen Proving Ground 
5. To produce a report documenting the findings of the inspection team for future use in developing the FSP, the preliminary risk assessment, and the demolition plan.

In this context, the term compartment denotes any generic or specific location or medium in which contamination may be found. Potential compartments include, but are not limited to, the following:

1. Interior of the building

a. Ventilation system - ducts, filters, blowers, vents, screens, hoods, etc.;

b. Drainage system - collection points, such as traps, sumps, and low areas in lines; areas below the floor in the vicinity of the underground drainage system;

c. Process-related equipment - piping, tanks, and pumps that are still present; and

d. Potential spillage areas*

(1) Floors - cracks, collection points, low areas, and high-spillprobability areas;

(2) Walls (up to approximately $8 \mathrm{ft}$ above floor level) - nonporous as well as porous materials in high-spill-probability areas;

2. Exterior to the building

a. Underground tanks, pipelines, and other underground structures;

b. Sumps;

c. Ditches and drainage channels, especially near points at which releases from inside the building may have occurred;

d. Areas along underground drainage and sewer lines;

${ }^{*}$ The nature of the material in a spill area is important because porous materials could contain contamination. Porous materials include cement, grouting, wood, and wallboard. Residual contamination may be present on the surfaces of nonporous materials. 
e. Areas in and around concrete pads (transformer pads, storage areas, etc.);

f. Areas in the vicinity of major electrical connections/components (for polychlorinated biphenyls [PCBs]); and

g. Areas in the vicinity of process-line connections with adjacent buildings. 


\section{Building Inspection Methodology}

The activities required to produce the initial building-inspection report can be divided into four groups: (1) conduct a historical records search, (2) detect and investigate by geophysical methods any underground structures associated with the building, (3) conduct a detailed visual inspe stion of the internal and external areas of the building, and (4) consolidate the information into a final inspection report.

A preliminary visit to the site before the actual inspection visit can be useful. The objectives of the preliminary visit are to obtain engineering drawings for the buildings to be insrected, identify health and safety issues that need to be addressed, discuss and resolve access restriction issues, identify needed support services, and identify potential problems that might hinder the execution of the inspection or the geophysical investigations. Photographs may be taken of the exterior of the buildings for use in planning the inspection visit. However, all photographs must be reviewed by an APG censor prior to their release, and adequate time must be allowed for this review in scheduling the work.

After the preliminary site visit, an inspection work plan and an associated health and safety plan are prepared for the specific building to be inspected. After APG staff reviews and approves these plans, the inspection can be conducted. Because of scheduling constraints and other considerations, it is convenient to prepare separate work and health and safety plans for the geophysics investigations, which take place entirely outdoors, and for the visual building inspections, which take place largely inside the buildings. It is desirable but not essential that the geophysics investigation be conducted simultaneously with the visual building inspection; currently, separate teams of ANL staff are involved in the two activities.

Specially designed, preprinted logbooks are used for building inspections. Each page in these logbooks poses specific questions concerning the building construction, mechanical systems, HVAC systems, remaining processing equipment, and other pertinent matters. The logbook is filled out by the investigation team during the building inspection. The logbook format is set up in such a way that the information gathered in the field is compiled in an orderly manner for each of the subject buildings. This method of compiling data enables the members of the inspection team to translate the field data into an inspection report efficiently and consistently. 


\section{Summary of Historical Records Search for Building E5190}

Building E5190 is part of the Plasticized White Phosphorus (PWP) production facility (Building E5188, formerly Building 90) in the Edgewood Area of the Aberdeen Proving Ground. The historical records (EAI Corporation 1989) for Building E5190 indicate that this building was planned and constructed in the early part of 1941 as a xylene storage facility. Building E5190 was actively used by the Army as a xylene storage facility from the time of its completion in 1942 through 1980. The records also show that the planning and construction of Building E5190 was done concurrently with the planning and construction of Building E5375, and that the structural aspects of these buildings are identical.

In April 1980, the 10,000-gal storage tank in Building E5190 was cleaned as follows (EAI 1989). Presumably, all remaining xylene was pumped out, although EAI does not explicitly mention this step. Then, alcohol (presumably ethanol) was placed in the tank; xylene is soluble in ethanol. The alcohol, containing some amount of xylene, was then pumped out and disposed of. Finally, approximately 600 gal of water was placed in the tank. No evidence was found during this investigation to indicate that the tank in Building E5190 was ever used again. The original engineering drawings used during the construction of the Building E5190 correspond with the building's present-day configuration. It is concluded that no major modifications were ever made to Building E5190, and that the engineering documents for this building accurately describe its current configuration. 


\section{Description of Building E5190}

This section contains a general description of Building E5190 and its contents and detailed descriptions of all significant features of the building. Figure 3 shows the location of Building E5190 in relation to the overall production area in the Edgewood area at APG, and Figure 4 shows Building E5190 in relation to other structures in its immediate vicinity.

Building E5190 is a one-room, single-story structure constructed of cast-in-place concrete. All four walls and the floor of E5190 are 1-ft-thick, steel-reinforced concrete (Whitman, Requardt and Smith Engineers 1941a, b, and c). The roof of the structure is constructed of lightweight structural steel covered with corrugated sheet metal. The exterior walls of the structure extend from the floor slab, which lies $4 \mathrm{ft}$ below ground level, to the roofline of the building. The building has seven windows; six of these windows are of standard design, measuring 84 in. tall $\times 78$ in. wide and consisting of a metal framework with multiple panes of glass. The seventh window is of the same basic design but is somewhat narrower than the other windows. Mounted below each window is an accompanying vent.

Building E5190 contains three sets of double doors. A set of $10-\mathrm{ft} \times 10-\mathrm{ft}$ double doors is located in the east wall of the building, and second and third sets of 8 - $\mathrm{ft} \times 8$ - $\mathrm{ft}$ double doors are located at the south and west walls of the building. The doors on the south wall of the building served as the main service entrance to the building. The purpose of the $8-\mathrm{ft} \times 8-\mathrm{ft}$ doors at the west end of the building is unclear. These doors may have been incorporated into the design of the building to facilitate the addition of a second tank. Alternatively, it is clear from the engineering drawings that Buildings E5190 and E5375 were designed and built together, and it may be that because the extra set of doors was needed in E5375, they were simply incorporated into the joint design. The doors of Building E5190 are constructed of wood cores covered with a reinforced metal skin; because of this design, the doors can withstand fire and will not fragment or splinter in the event - an explosion. The building contains a single, horizontal, 10,000-gal liquid storage tank. This tank corresponds to APG storage tank record number 91695 .

Building E5190 was designed and used as a flammable liquid storage facility. The floor of the building was placed below grade, and the 1-ft-thick concrete walls and floor for the building were cast monolithically (i.e., in one piece). In the event of an explosion, this building would vent most of the initial force of the explosion upward, thus containing the force of the explosion to the immediate area of the building. This design also allowed Building E5190 to act as a primary containment pool if the tank ruptured and leaked.

The building's HVAC system consists of a single, roof-mounted, electrically powered exhaust fan. This fan and associated ductwork are located in the northwest corner of the building. A series of large wall vents is located below each of the windows in the building. Two winddriven turbine vents are located on the roof of the building. This combination of wall and roof vents supplies the building with an abundant quantity of fresh air. When used in conjunction with the exhaust fan, rapid air changes in this building can be achieved. 


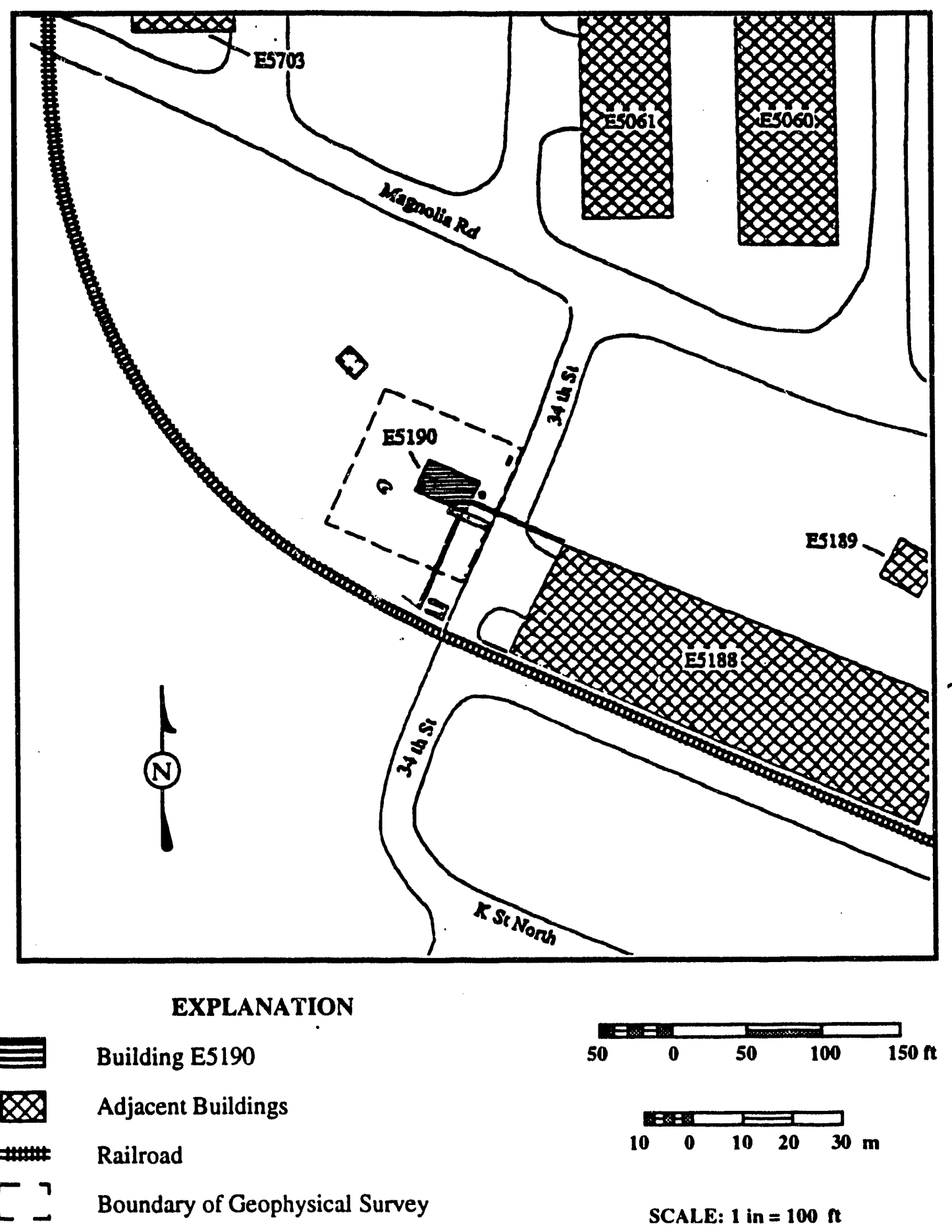

FIGURE 3 General Site Map of Aberdeen Proving Ground in the Vicinity of Building E5190 


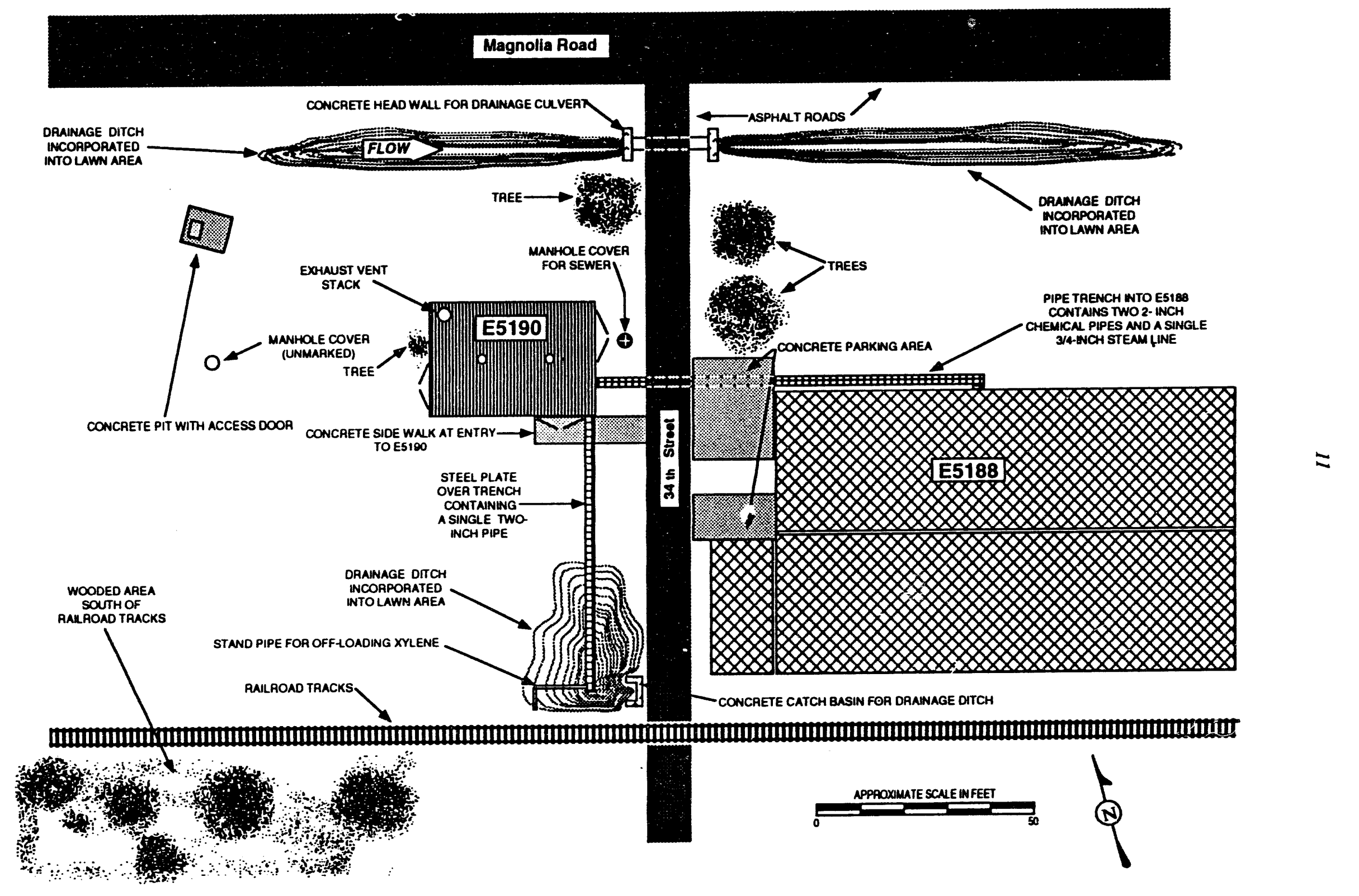

FIGURE 4 Building E5190 Site Plan 
The building contains two floor drains. The outfall piping for these drain lines was not located during either the building investigation or the geophysical survey. Both of these drains were sealed at the time of the building inspection by drain-filling plugs that extend approximately one or two inches above the floor surface. Most of the piping in the building is connected and still in place.

A pipe trench connects Building E5190 with the railroad siding directly to the south of the building (see Figure 4). Another pipe trench connects the building with the adjacent, main PWP production building (Building E5188). These trenches contain pipes that were used for pumping xylene from tank cars at the siding into Building E5190 and from Building E5190 to Building E5188.

The current condition of Building E5190 is fair, and the building is structurally sound.

\subsection{Site Description}

\subsubsection{Address}

Building E5190 is located on the west side of 34th Street, approximately $100 \mathrm{yd}$ south of Magnolia Road in the Canal Creek area of Aberdeen Proving Ground (Figure 3).

\subsubsection{Proximity to Other Buildings}

This building is part of the PWP production facility at that same location (Figures 3 and 4).

\subsubsection{Exterior Footprint Dimensions}

Building E5190 is $40 \mathrm{ft}$ long $\times 25 \mathrm{ft}$ wide (see Figure 4).

\subsubsection{Surface Soils and Topographical Conditions}

The area directly surrounding Building E5190 is flat and dry, with a gentle slope away from the building to the south. Very little of the surface soil surrounding the building is exposed; however, what is visible appears to be a course, gravel-like soil. 


\subsubsection{Vegetation in the Immediate Vicinity}

The area surrounding Building E5190 consists primarily of lawn (cut grass) that extends right up to the building foundation on all sides. Several medium-sized trees (30 to $40 \mathrm{ft}$ ) are to the east of the building (Figure 4).

\subsubsection{External Aboveground Structures or Equipment}

No external aboveground structures or equipment is associated with Building E5190 within the study area.

\subsubsection{Connections with Adjacent Buildings}

Building E5190 is connected to the PWP production Building E5188 by an underground, open-top, concrete, pipe trench (Figure 4). This trench extends from the east side of Building E5190 for approximately $80 \mathrm{ft}$ before reaching Building E5188. It runs parallel to the north side of E5188 for an unmeasured distance before turning and entering Building E5188 from the north. The trench still houses three pipes, two 2-in. pipes that were used to transport xylene into and possibly out of E5188 and a single 1-1/2-in. insulated steam line to deliver steam to the heating unit in Building E5190. This steam line may also have ensured that the trench did not become frozen or icebound in the winter months. Building E5190 is also connected to a railroad siding approximately $100 \mathrm{ft}$ south of the building by a similar pipe trench (Figure 4). This trench contains a single, 2 -in. pipe used for off-loading xylene from railroad tank cars. The pipe trenches are constructed of approximately 3-in.-thick cast-in-place concrete. The interior dimensions of these trenches are as follows: east-west trench 16 in. wide $\times 18$ in. deep and north-south trench 12 in. wide $\times 18$ in. deep. In low areas within the trenches, a thick layer of silt covers the bottom, and in some of the level areas, the trenches contained standing water. The pipe trenches are covered with removable 1/4-in. diamond-plate steel panels, each about $4 \mathrm{ft}$ long.

\subsubsection{Location and Type of Underground Structures}

Approximately $100 \mathrm{ft}$ to the northwest of Building E5190 is an underground concrete utility chamber (type of utility unknown ). This chamber is equipped with a metal hatch-type door located in a concrete slab at ground level. Approximately $75 \mathrm{ft}$ to the south of this utility chamber is a standard utility access point (manhole) (type of utility unknown). Directly outside the east doors of Building E5190, situated between the building and 34th Street, is a second standard manhole marked "sewer." None of the underground utility manholes or structures were investigated during this inspection visit. 


\subsubsection{Location and Type of Surface Drainage System}

On the north side of the building, there is a man-made storm drainage ditch incorporated into the lawn area surrounding Building E5190. This drainage ditch is oriented in an east-west direction and is located midway between Building E5190 to the south and Magnolia Road to the north (Figure 4). A second drainage ditch with a catch basin is directly to the south of Building E5190 (Figure 4). This drainage ditch serves the area on the north side of the railroad tracks (Figure 4). From this location, railroad cars of xylene were off-loaded via the pipe trench to the tank in Building E5190 (Figure 4). At the time of this inspection, the catch basin at this location contained about $1 / 2$ in. of standing water with an oily film floating on it.

\subsubsection{Utility Access Points (Manholes) and Utility Type}

See Section 4.1.8.

\subsubsection{Piping Exiting the Building and Entering the Ground}

See Section 4.1.7.

\subsubsection{Location and Direction of Nearby Roads and Sidewalks}

Building E5190 has a concrete entrance slab at the south entrance to the building. Thirtyfourth Street, a 20-ft-wide asphalt street running in a north south direction, is directly east of the building (Figure 4 ).

\subsection{North Exterior Elevation}

\subsubsection{Dimensions}

The north elevation of Building E5190 measures $14 \mathrm{ft} 8 \mathrm{in}$. tall $\times 40 \mathrm{ft}$ wide (Figure 5).

\subsubsection{Construction Materials}

The exterior walls of the building are 12-in.-thick, cast-in-place steel-reinforced concrete. 


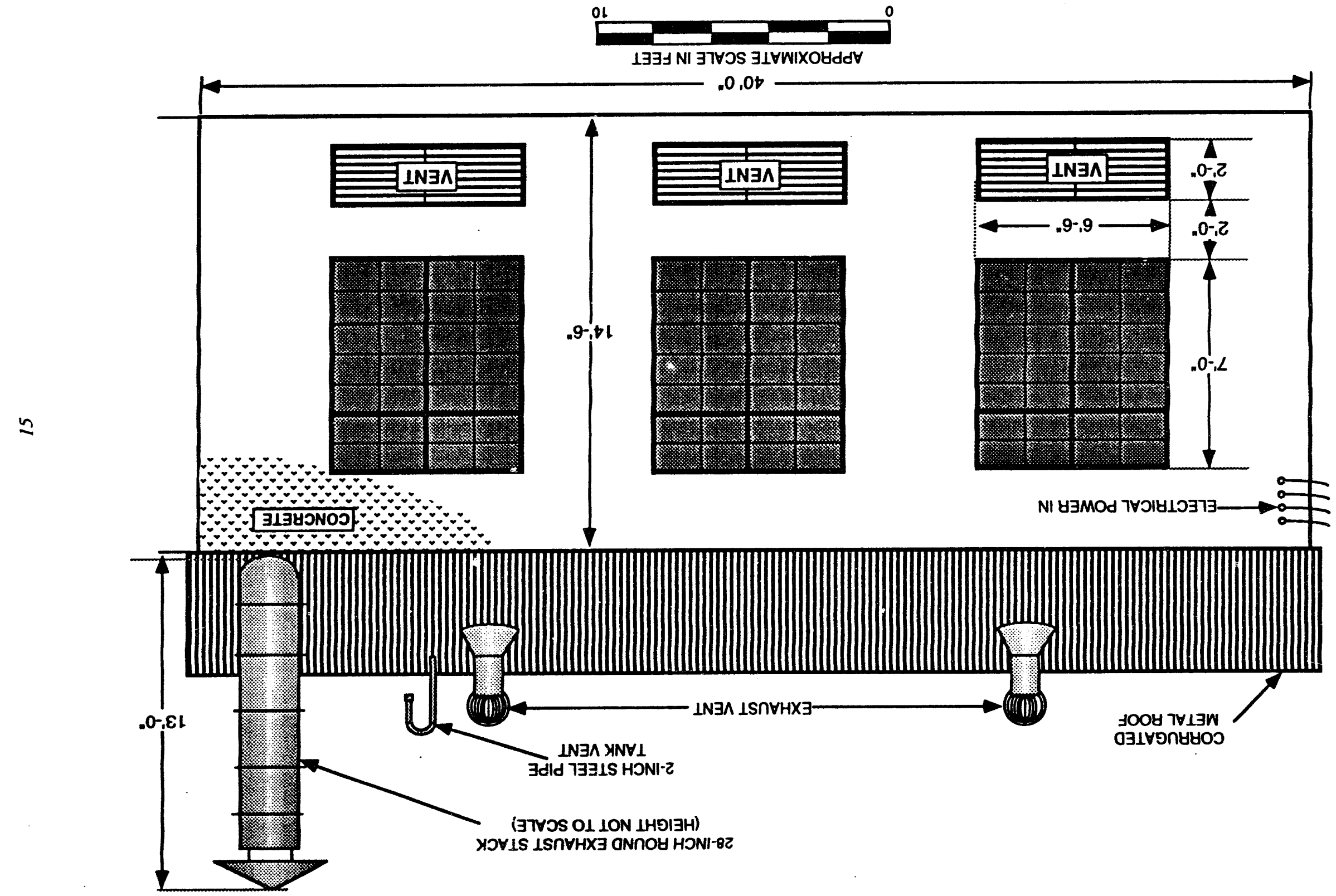




\subsubsection{Doors and Windows}

No doors are present in this elevation. Three window/vent combinations are on the north elevation of E5190. Windows in E5190 are typical in design, measuring 78 in. wide $\times 84$ in. high. They are constructed of a metal framework with multiple panes of glass. Each window has an accompanying 24 -in.-tall $\times 78$-in.-wide vent mounted directly below it. The north elevation E5190 contains three of these window/vent combinations (Figure 5).

\subsubsection{Piping along or Connected with this Face of the Building}

The north exterior elevation of E5190 contains no piping or evidence that piping ever existed at this location.

\subsubsection{Utility Connections}

All utilities to Building E5190 appear to be physically connected to the building, although the building is without the benefit of utilities, probably because the switches and valves that control the utilities have been shut off upstream of the building.

\subsubsection{External Equipment or Structures}

There are no external structures or equipment in the north elevation of E5190.

\subsubsection{Vegetation}

Located between Buildings E5190 and Magnolia Road is an expansive area of lawn (Figure 4).

\subsubsection{Overall Condition}

The overall condition of this elevation of the building is good. All of the components that make up this elevation remained in place " the time of this investigation. 


\subsection{East Exterior Elevation}

\subsubsection{Dimensions}

The east elevation of Building E5190 measures $18 \mathrm{ft} 6 \mathrm{in}$. at the south end of the roof to $14 \mathrm{ft} 6 \mathrm{in}$. at the north end, and the overall width of the building at this elevation is $25 \mathrm{ft}$ (Figure 6).

\subsubsection{Construction Materials}

The exterior walls of the building are 1-ft-thick, cast-in-place, steel-reinforced concrete.

\subsubsection{Doors and Windows}

The east elevation of Building E5190 contains one set of double doors measuring $10 \mathrm{ft} \times 10 \mathrm{ft}$. These doors appear to be constructed of wood cores and wrapped with a metal covering (Figure 6).

There is a single window/vent combination in the east elevation of E5190. The only window in Building E5190 that differs in size from all other windows in the building, this window opening measures 84 in. tall $\times 40$ in. wide. There is an accompanying wall vent directly below the window that measures 40 in. in width and 24 in. in height (Figure 6).

\subsubsection{Piping along or Connected with this Building Elevation}

The east exterior elevation of E5190 contains no piping or evidence that piping ever existed at this location.

\subsubsection{Utility Connections}

None present in the east elevation. 


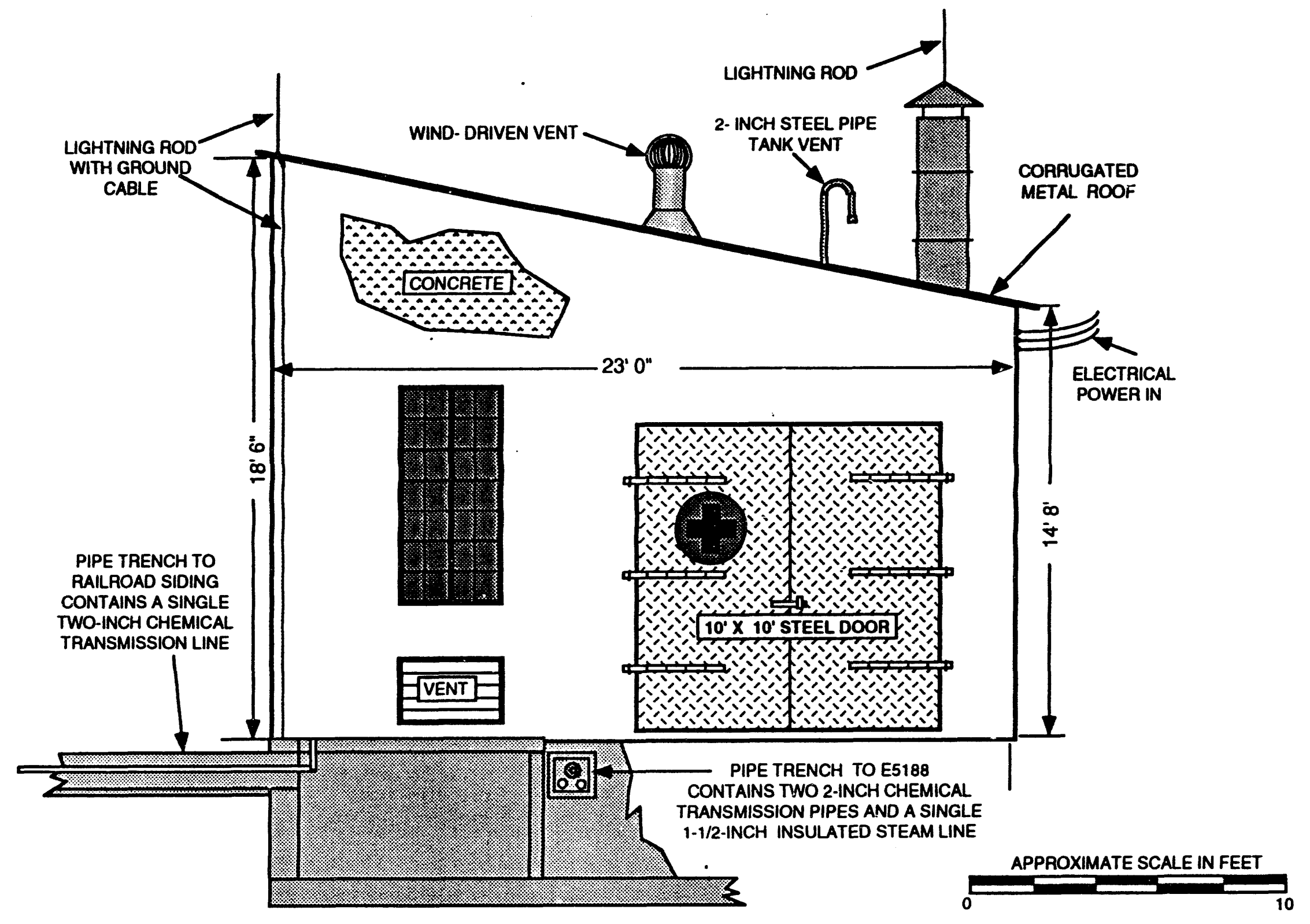

FIGURE 6 Building E5190 East Exterior Elevation 


\subsubsection{External Equipment or Structures}

A lightning protection system is located externally at the southeast corner of Building E5190. This system consists of a single cable that extends from the lightning rod located above the roof level of the building to the ground rod at the base of the building.

\subsubsection{Vegetation}

The grass extends up to the foundation along the east elevation of Building E5190. No other vegetation is present.

\subsubsection{Overall Condition}

The overall condition of this elevation of the building is good. All of the components that make up this elevation remained in place at the time of this investigation.

\subsection{South Exterior Elevation}

\subsubsection{Dimensions}

The south elevation of Building E5190 measures $18 \mathrm{ft} 6$ in. tall $\times 40 \mathrm{ft}$ wide (Figure 7).

\subsubsection{Construction Materials}

The exterior walls of the building are 1-ft-thick, cast-in-place, steel-reinforced concrete.

\subsubsection{Doors and Windows}

The south elevation of Building E5190 contains one set of double doors measuring $8 \mathrm{ft} \times 8 \mathrm{ft}$. These doors appear to be constructed of wood cores covered with metal (Figure 7). There are two window/vent combinations in the south elevation of E5190 (Figure 7). 


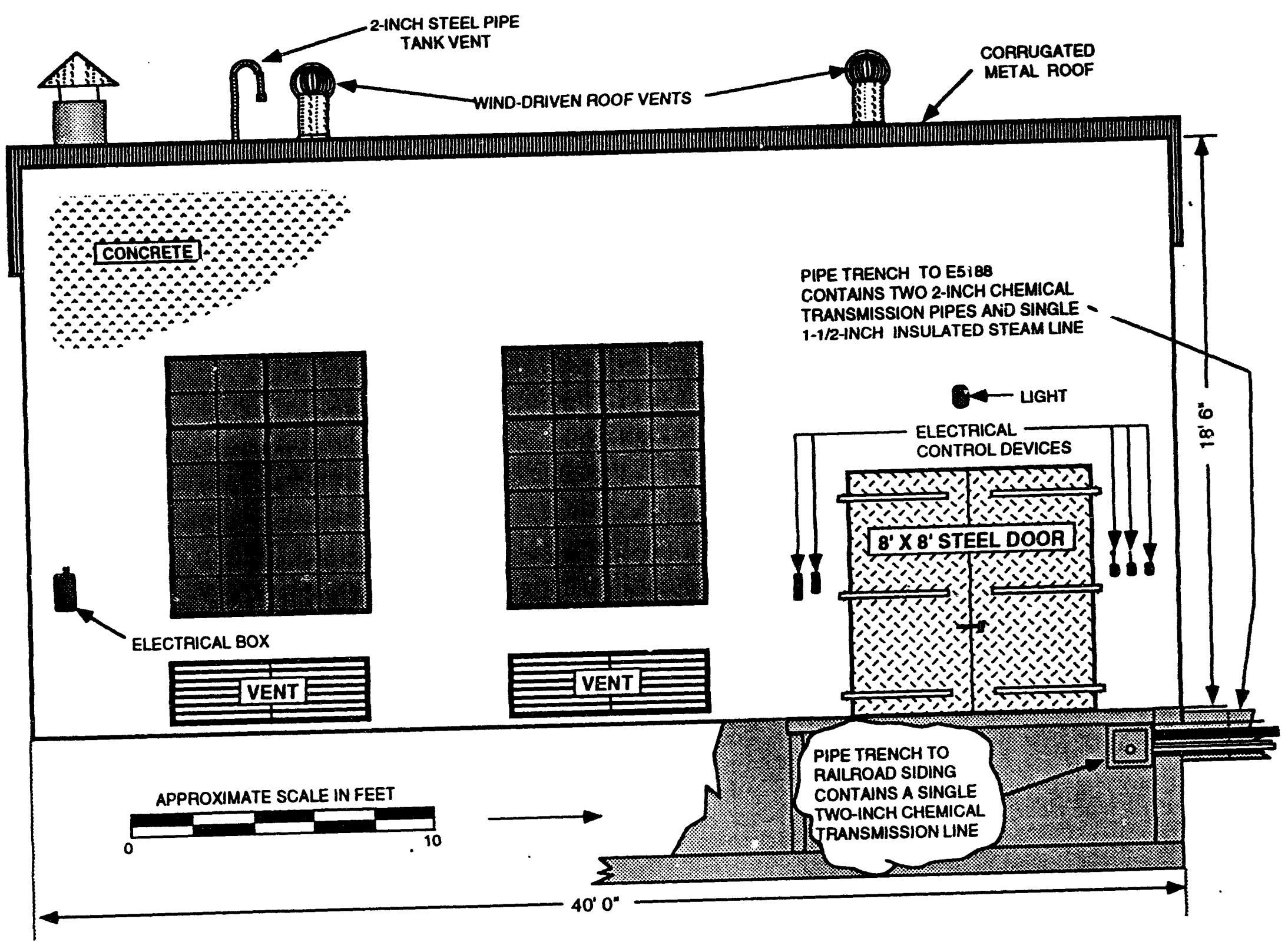

FIGURE 7 Building E5190 South Exterior Elevation 


\subsubsection{Piping along or Connected with this Face of the Building}

The south exterior elevation of E5190 contains no piping or evidence that piping ever existed at this location (Figure 7).

The pipe trench that connected Building E5190 with the ailroad siding to the south of the building (Figures 4 and 7) exits the building (underground) at the southeast corner.

\subsubsection{Utility Connections}

No utility connections are associated with this elevation of Building E5190.

\subsubsection{External Equipment or Structures}

Present in this elevation of Building E5190 are a number of electrical control boxes on both sides of the main entrance doors (Figure 7).

\subsubsection{Vegetation}

Other than grass, which extends up to the building foundation, no vegetation is present near the south elevation.

\subsubsection{Overall Condition}

The overall condition of this elevation of the building is good. All of the components that make up this elevation remain in place at the time of this investigation.

\subsection{West Exterior Elevation}

\subsubsection{Dimensions}

The west elevation of Building E5190 measures $18 \mathrm{ft} 6 \mathrm{in}$. at the south end of the roof to $14 \mathrm{ft} 6 \mathrm{in}$. at the north end; the overall width of the building along this elevation is $25 \mathrm{ft}$ (Figure 8). 


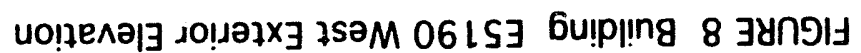

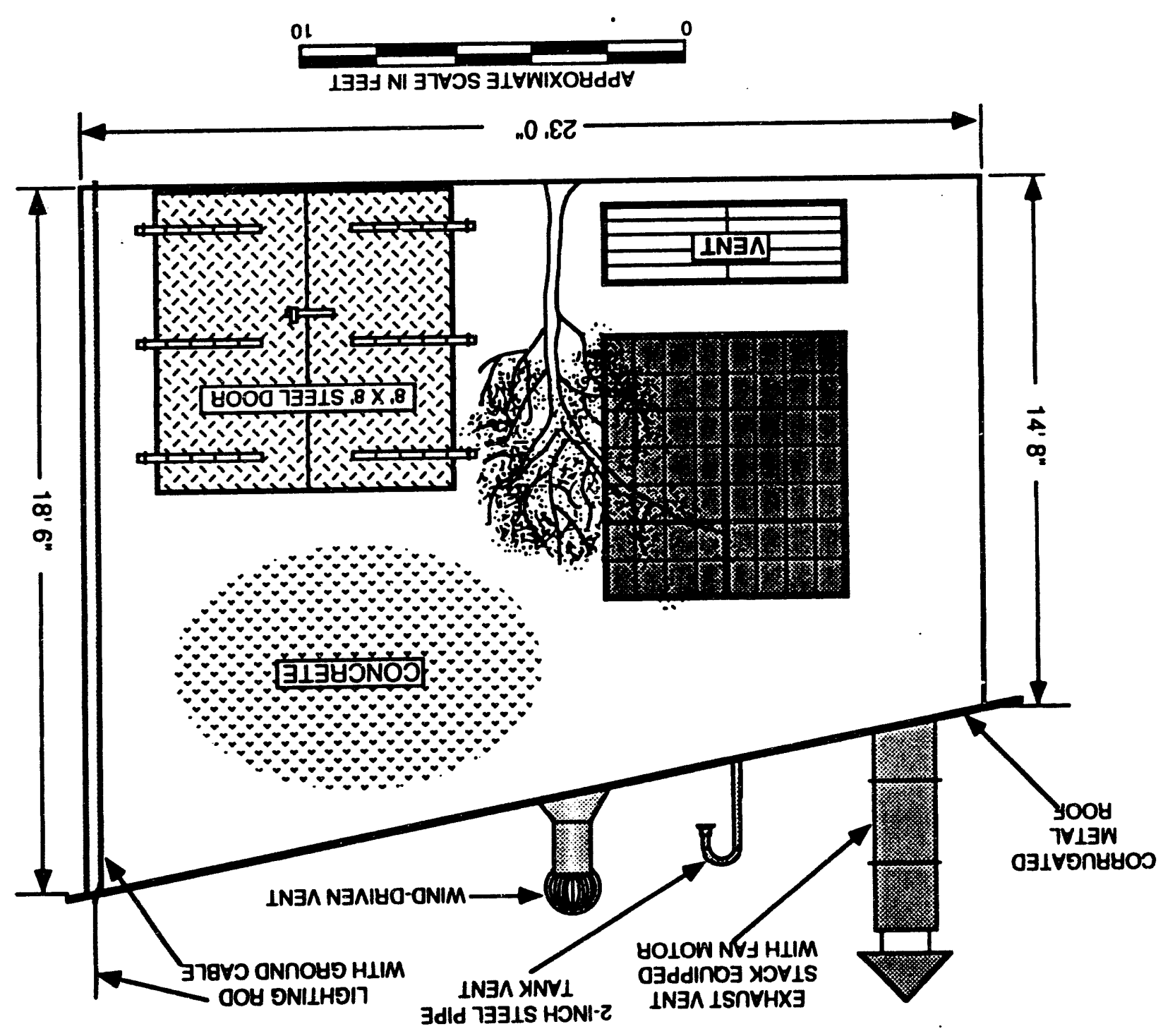




\subsubsection{Construction Materials}

The exterior walls of the building are 1-ft-thick, cast-in-place, steel-reinforced concrete.

\subsubsection{Doors and Windows}

The west elevation of Building E5190 contains one set of double doors, measuring $8 \mathrm{ft} \times 8 \mathrm{ft}$. These doors appear to be constructed of wood cores wrapped with a metal covering.

The west elevation of E5190 has a single window of the standard design used in this building (Figure 8) (see Section 4.2 .3 of this report).

\subsubsection{Piping along or Connected with this Face of the Building}

The west elevation of the Building E5190 is devoid of exterior piping or evidence of any former piping.

\subsubsection{Udility Connections}

No utilities are associated with the west elevation of Building E5190.

\subsubsection{External Equipment or Structures}

None present in the west elevation.

\subsubsection{Vegetation}

A single 10-ft-tall tree is growing near the west end of E5190 (Figure 7).

\subsubsection{Overall Condition}

The overall condition of this elevation of the building is good. All of the components that make up this elevation remain in place at the time of this investigation. 


\subsection{Roof}

\subsubsection{Type and Dimensions}

Building E5190 has a shed-type roof measuring $42 \mathrm{ft}$ long $\times 27 \mathrm{ft}$ wide.

\subsubsection{Height}

The high end of the roof (south) at E5190 is $18 \mathrm{ft} 6 \mathrm{in}$. above ground level, and the low end of this roof (north) is $14 \mathrm{ft} 8 \mathrm{in}$. above ground level (Figure 5).

\subsubsection{Surface Materials}

Building E5190 has a corrugated sheet-metal roof (Whitman, Requardt and Smith Engineers 194lb).

\subsubsection{Structural Materials Used in Roof-Support System}

The roof of Building E5190 is supported by a lightweight structural-steel framework. This system uses a single load-bearing steel I-beam, which bisects the building on a north-south axis. This I-beam supports a steel roof joist, which is placed $2 \mathrm{ft}$ on center and extends from the I-beam to the east and west walls of the building.

\subsubsection{Condition}

The roof of Building E5190 appears to be in fair condition.

\subsubsection{Equipment Located at, on, or in the Roof}

The fan motor for the building exhaust system is located in ductwork that extends above the northwest corner of the roof. 


\subsubsection{Chimneys, Roof Vents, or Vent Stacks}

Building E5190 has a single 2-in. iron pipe passing through the roof of the building. This pipe is a vent for the 10,000-gal tank located within the building. At the northwest corner of the roof, a 28 -in., round, galvanized-metal ventilation exhaust stack extends $13 \mathrm{ft}$ above the roof. This vent stack is equipped with a conical top (for protection from rainfall) and a lightning rod. Two 15-in., round, wind-driven ventilators are also located on the roof.

\subsubsection{Present Piping and Evidence of Former Piping Located on the Roof}

All piping on the roof of Building E5190 is described in Section 4.6.7.

\subsection{Interior Floor Plan}

\subsubsection{Interior Room Number and Dimensions}

Building E5190 is a single-story one-room building with interior dimensions of $38 \mathrm{ft}$ long $\times 23 \mathrm{ft}$ wide. Figure 9 shows the floor plan for Building E5190.

\subsubsection{Room Perimeter Walls}

The walls of the room coincide with the exterior walls of the building, which are 1-ft-thick, cast-in-place, steel-reinforced concrete. These walls extend from the floor of the building ( $4 \mathrm{ft}$ below exterior grade) to the roofline of the building. The walls of this structure are in good condition with regard to their structural integrity. Figures 10-13 show north, east, south, and west interior elevations, respectively.

\subsubsection{Floor Construction Materials, Condition, and Configuration}

Building E5190 has a 1-ft-thick, cast-in-place concrete floor installed $4 \mathrm{ft}$ below the surrounding exterior grade of the building. The floor of E5190 is intact and in good condition for its age. There is no evidence to suggest that the floor of this building was modified in any way. No major cracks were identified.

In the southeast corner of the building, there is a $7-\mathrm{ft} \times 12$-ft concrete platform elevated approximately $4 \mathrm{ft}$ above the building's main floor. The main entrance to the building leads onto 


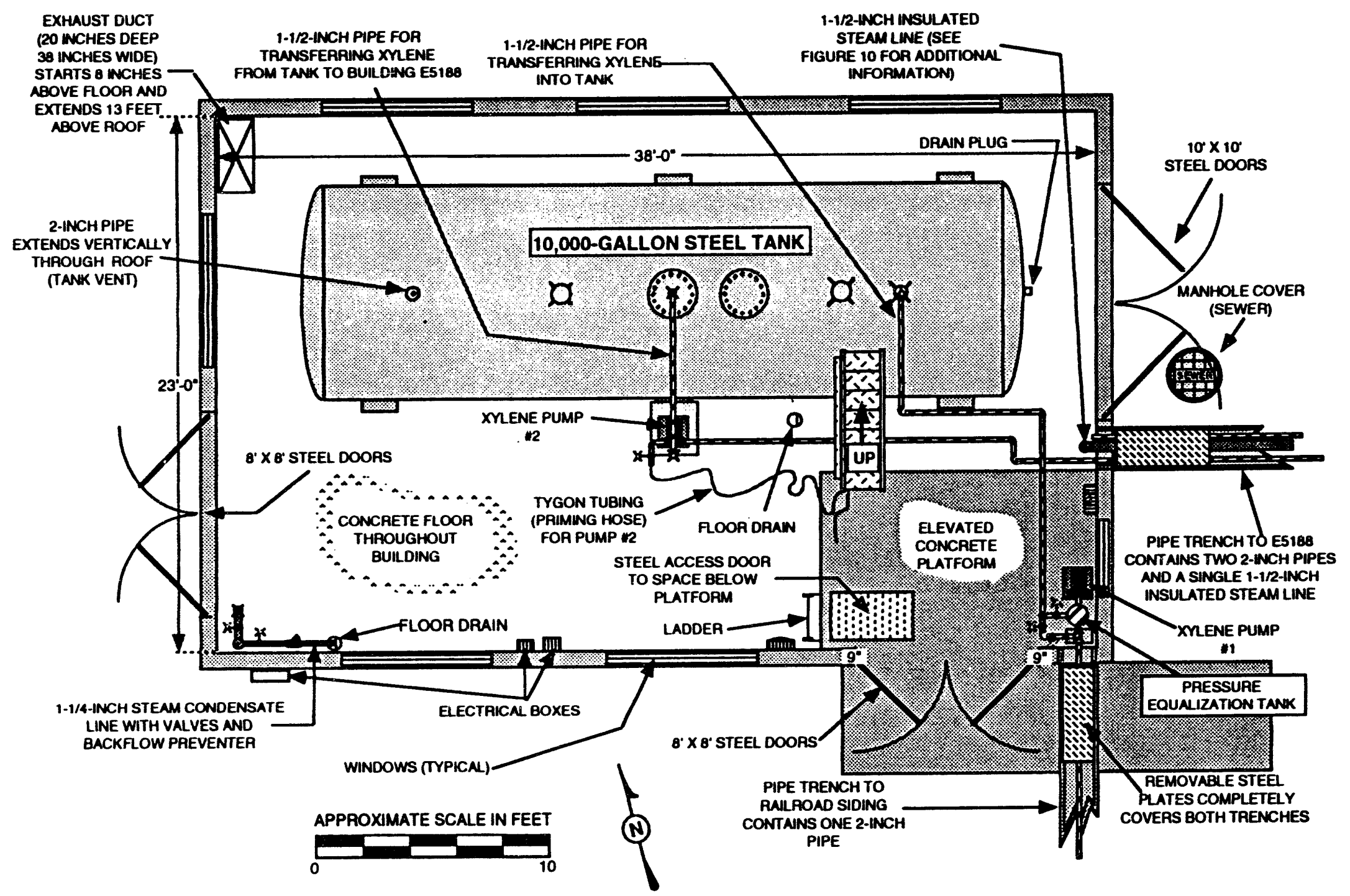

FIGURE 9 Building E5190 Floor Plan 


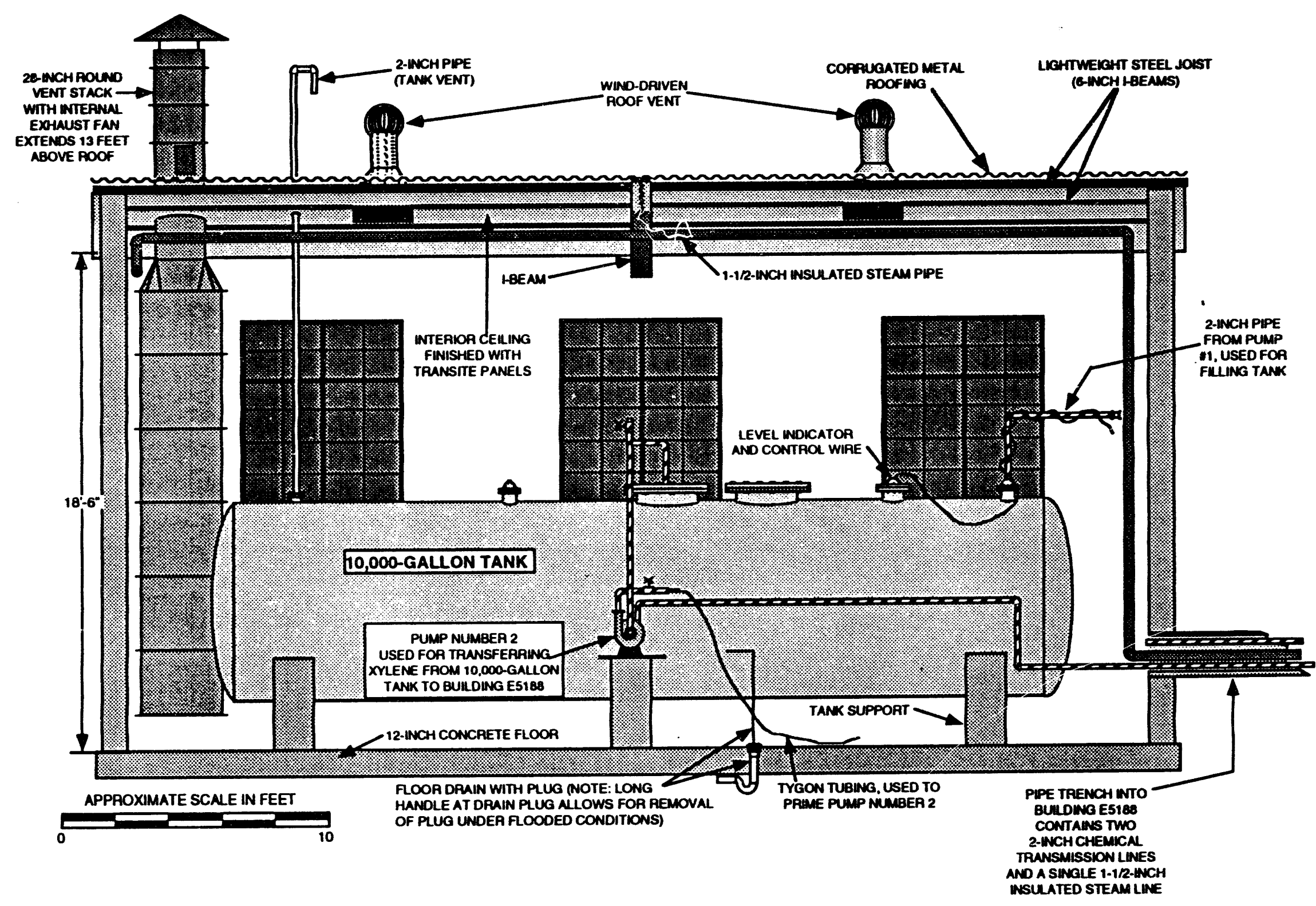

FIGURE 10 Building E5190 North Interior Elevation 
APPAOXIMATE SCALE IN FEET

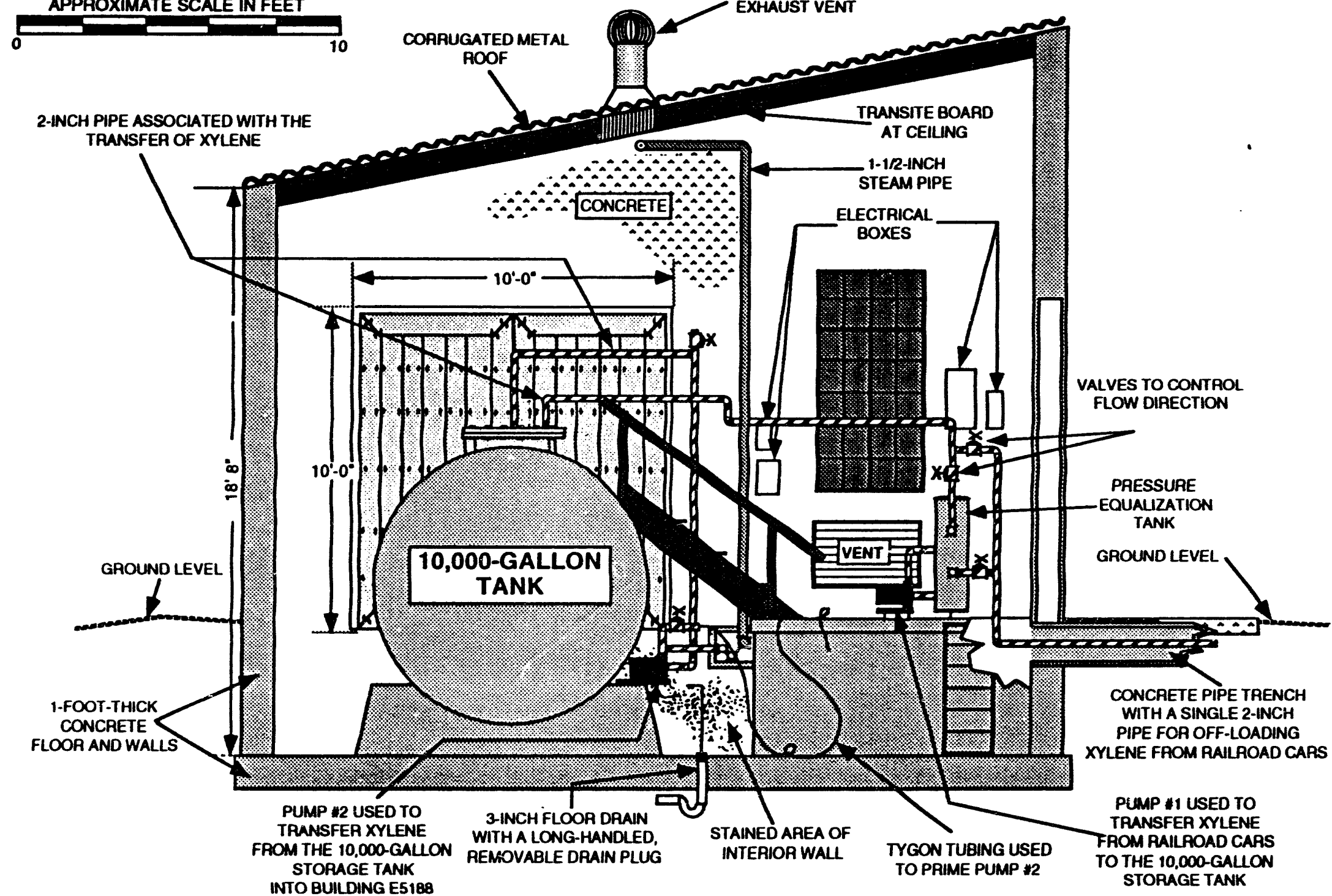

FIGURE 11 Building E5190 East Interior Elevation 


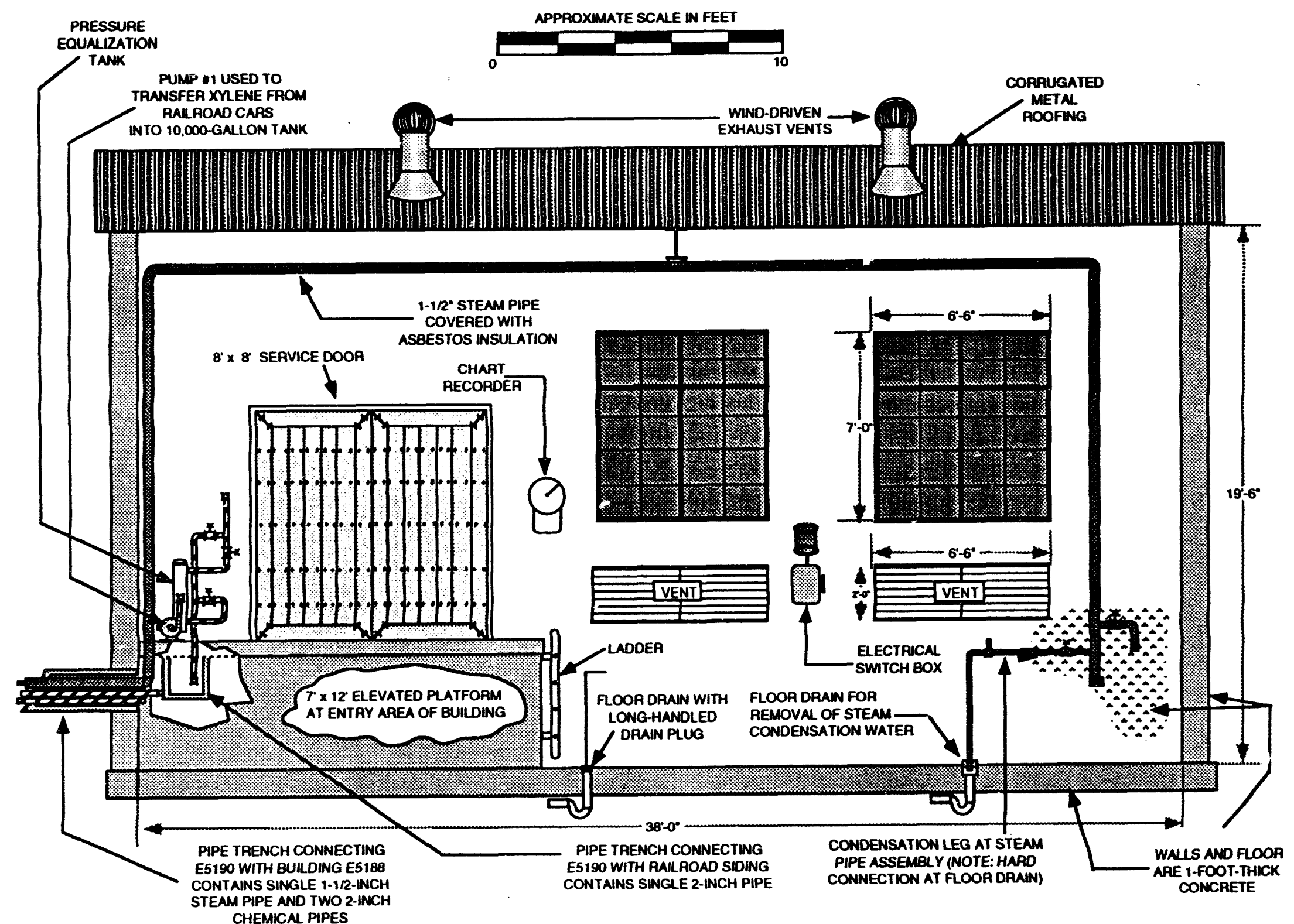

FIGURE 12 Building E5190 South Interior Wall 
BUILDINGS WNLLS ARE 1-FOOT-THICK. STEEL. REINFORCED CONCRETE

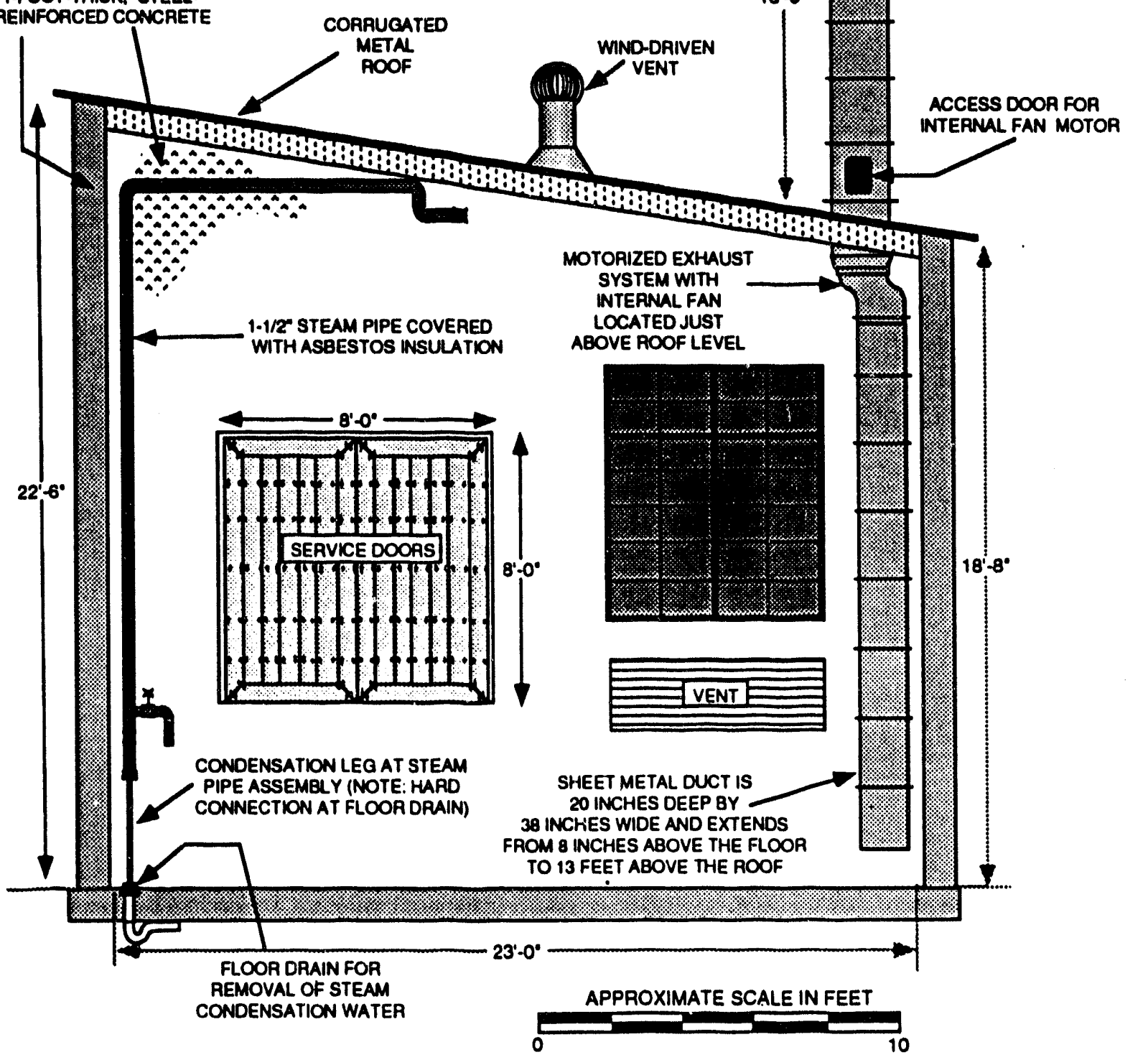

FIGURE 13 Building E5190 West Interior Wall 
this platform. A ladder leads down to the iloor level of the building (Figure 13). This platform seems to have been the main work area within the building. The area below the platform is empty unused space (Whitman, Requardt and Smith Engineers 194la; see also Figure 12).

\subsubsection{Floor Penetrations}

The building contains two 2-1/2-in. floor drains (Figure 9). The outfall piping for these drain lines was not located during either the building inspection or the geophysical survey. The first of these drains, which is located approximately $5 \mathrm{ft}$ northwest of the elevated platform, is equipped with a plug. This drain plug has a 4-ft-long metal rod extending vertically above the floor; this rod acts as a handle for the removal of the drain plug in the event that the building is flooded. The second floor drain is located along the south interior wall of the building, approximately $7 \mathrm{ft}$ east of the southwest corner of the building, and is also equipped with a plug. This drain is dedicated to the removal of condensation water resulting from the steam heating system. A single 1-in. pipe is sealed in the drain plug (Figure 10) (Whitman, Requardt and Smith Engineers 1941a).

\subsubsection{Location and Size of Interior Partitions}

Building E5190 is a single-room structure containing no interior partitions.

\subsubsection{Equipment or Supplies Present}

Building E5190 contains a single 10,000-gal storage tank, number 91695 in APG's liquid storage tank record system. The approximate dimensions and the location of this tank within the building are shown in Figure 9.

The cylindrical welded-seam steel tank is oriented horizontally and parallel with the building's long axis. The side of this tank is approximately $4 \mathrm{ft}$ from the north wall of the building. The tank has six openings; five of these openings are sealed shut with steel caps (Figure 10). The sixth opening is located at the far west end of the tank and is connected to a 2-in. pipe that rises vertically through the roof of the building and that serves as a vent for the tank (Figure 10).

The building also contains two electric pumps. The first of these pumps (pump \#1) is located just inside the main entrance doors, at the south side of the building (Figures 9 and 11). This pump and its associated piping were used for off-loading xylene from railroad cars to the 10,000-gal tank in Building E5190. This system uses a series of pipes to connect the 2-in. pipe in the pipe trench to the 10,000-gal tank (Figures 9,10,11, and 12). Associated with this system is a small (10 gal) vertical tank. This tank was used for pressure equalization (surge protection) in 
the xylene pumping system; it also ensured that pump \#1 would not lose its prime. The piping configuration associated with pump \#1 and the surge protection tank involve a series of valves that enable the system to pump xylene into as well as out of the 10,000-gal tank. All of the piping in Building E5190 associated with the tank filling system, including the surge protection tank, is painted yellow.

The second pump (pump \#2) is located at the mid-point of the 10,000-gal tank. Pump \#2 is mounted on the edge of the center concrete tank support on the south side of the tank, about three feet above the floor of the building. This pumping system draws xylene from the tank and delivers it to Building E5188 via the pipe trench at the east side of Building E5190. Pump \#2 is equipped with a priming valve. Approximately $20 \mathrm{ft}$ of $1 / 4$-in. plastic tubing, which is used to deliver xylene to the pump if the pump lost its prime, is connected to the priming valve (Figure 10).

A 20-in. $\times 38$-in. sheet-metal exhaust duct is located in the interior northwest corner of the Building E5190. This duct starts eight inches above floor of the building and extends through the building roof. The exterior portion of this exhaust system consists of the round sheet-metal vent stack described in Section 4.6.7 (Figures 10 and 13).

\subsection{North Interior Elevation}

\subsubsection{Wall Characteristics}

Because E5190 is a one-room building, there are no interior walls. See Section 4.7.2.

\subsubsection{Interior Wall Finish Materials}

The interior walls of Building E5190 are raw, uncoated concrete.

\subsubsection{Piping Attached to or Associated with the Wall}

No piping is attached to or associated with the wall.

\subsubsection{Equipment Connected with this Elevation}

The ventilation ductwork located in the northwest corner and described in Section 4.7 .8 is shown in this elevation. 


\subsubsection{Doors and Windows}

There are no doors at the north elevation of this building. Refer to Section 4.2.3 of this report for a description of the window (Figure 10).

\subsection{East Interior Elevation}

\subsubsection{Wall Characteristics}

Refer to Section 4.4.2. See also Figure 11.

\subsubsection{Interior Wall Finish Materials}

The interior walls of Building E5190 are raw, uncoated concrete. Around and near the area of the east wall (where the opening of the pipe trench appears) is an area of staining or discoloration that appears to have originated from the pipe trench. The stained area is orange, probably as a result of rust from the metal pipes and covers associated with the trench. The concrete in the area near the opening of the pipe trench is pitted and flaking.

\subsubsection{Piping Attached to or Associated with the Wall}

The east wall of Building E5190 contains elements of two different xylene pumping systems. The first of these systems is associated with the tank filling operations (Figures 9,11 , and 12). The second system involves the pumping of xylene from the 10,000-gal tank into Building E5188. The opening for the pipe trench that connects Building E5190 to Building E5188 is shown in Figure 11. Through this trench, a 1-1/2-in. (asbestos-insulated) steam line and a single 2-in. xylene pipe enter the building (Figures 10 and 11). The second xylene pipe in the pipe trench does not extend into the building.

\subsubsection{Equipment Connected with this Elevation}

See Section 4.7 .8 of this report. Also see Figures 9 through 13. 


\subsubsection{Doors and Windows}

Refer to Section 4.2 .4 of this report. Also see Figures 6 and 11.

\subsection{South Interior Elevation}

\subsubsection{Wall Characteristics}

Refer to Section 4.4.2. Also see Figure 12.

\subsubsection{Interior Wall Finish Materials}

The interior walls of Building E5190 are raw, uncoated concrete.

\subsubsection{Piping Attached to or Associated with the Wall}

The south interior elevation of E5190 contains elements of two of the building's plumbing systems. The first of these systems is located in the southwest interior corner of the building. A 1-1/2-in. insulated steam line for the heating unit that has been removed from the building remains at this location (Figure 12). This steam system has an associated condensation leg that is hardpiped directly into a floor drain (Figure 12). The second piping system in this elevation is associated with the tank filling operation and is located at the elevated platform in the southeast corner of the building (see Section 4.7.8 this report and Figures 9, 11, and 12). The opening for the pipe trench that connects the building to the railroad siding to the south is located in the southeast corner of the building, directly beneath the elevated platform (Figure 12).

\subsubsection{Equipment Connected with this Elevation}

Refer to Section 4.7.8 of this report and see Figures 9, 7, and 12.

\subsubsection{Doors and Windows}

Refer to Section 4.4 .3 of this report. Also see Figures 7 and 12. 


\subsection{West Interior Elevation}

\subsubsection{Wall Characterịtics}

Refer to Section 4.5.2. Also see Figure 13.

\subsubsection{Interior Wall Finish Material}

The interior walls of Building E5190 are raw or uncoated concrete (Figure 13).

\subsubsection{Piping Attached to or Associated with the Wall}

The only piping associated with the west wall of the building is the $1-1 / 2$-in. steam line; see Figure 13.

\subsubsection{Equipment Connected with this Elevation}

The only other equipment that is associated with west interior elevation is the sheet-metal exhaust duct that extends from the floor of the building through the roof of the building (Figures 9, 10, and 13).

\subsubsection{Doors and Windows}

Refer to Section 4.5.3 of this report. Also see Figures 8 and 13.

\subsection{Ceiling and Roof}

\subsubsection{Construction and Condition}

The roof and ceiling of Building E5190 are constructed of lightweight structural steel. Five 6-in. steel roof joists (concealed steel I-beams) spaced $4 \mathrm{ft}$ apart (center-to-center) traverse the building in an east-west direction. These joists are supported at the ends by the exterior wall of the building and at the center by a one-foot I-beam that bisects the building in a north-south direction (Figure 10). 
The ceiling of Building E5190 is finished with Transite panels and appears to be in fair condition (Figure 10).

\subsubsection{Piping and Equipment}

Crossing the entire length of the ceiling in an east-west direction is the $1-1 / 2$-in. insulated steam line (Figure 10). The roof of E5190 has four mechanical penetrations that consisting of two roof vents, the exhaust duct work, and the vent pipe for the 10,000-gal tank. 


\section{Summary of Geophysics Investigation}

Simultaneously with the building investigation, ANL personnel conducted a geophysical survey of the area directly surrounding Building E5190. The methodology, results, and discussion are given by Miller et al. (1992). Geophysical measurements were taken by using ground-penetrating radar (GPR), a horizontal direct-current electrical resistivity (DCER) meter, and a magnetic gradiometer/metal detector. Specific results from this geophysical survey are described below.

- Many small magnetic anomalies were detected by using the magnetic gradiometer. The magnetic anomalies are due to small, scattered, metallic debris that probably poses no environmental hazard. No linear features that might result from ferrous metal pipelines or other such structures were observed in the magnetic data.

- An approximately linear north-south feature was seen in the resistivity data near the western edge of the study area. A more intense, approximately linear feature was seen extending in a generally westerly direction from the southwest part of the building. This feature passes directly over the depressed area located about $30 \mathrm{ft}$ west of the southwest corner of the building. Such resistivity features outline trends of increased saturation. If liquid contaminants were present in the subsurface, they would be associated with the feature trending westerly from the building, particularly in the area around the surface depression. The north-south feature may represent a buried sewer line, especially because a utility access portal is located west of the study area and along the same line. The feature extending from the building may be another (nonmetallic) sewer line connected either with the building drains or with the manhole marked "sewer" located just east of the building. The depression may be the result of leakage that has caused the area to be undermined. GPR and magnetic measurements in the area show no corresponding features or anomalies.

- Several small anomalies were observed with the GPR; these anomalies appear to be due to small, metallic sources that probably pose no environmental hazard. 


\section{Summary and Discussion}

\subsection{Building Operations}

Building E5190 functioned solely as a xylene storage facility in support of the production of PWP in Building E5188. Xylene would arrive at this facility by railroad cars and would then be pumped into the 10,000 -gal tank for storage. The xylene would remain stored until it was needed for the production of PWP, when it would be pumped into Building E5188.

\subsection{Summary of Potentially Contaminated Compartments}

The following list of compartments represents locations or areas within Building E5190 and the surrounding area that should be considered as potentially contaminated. These areas represent the most likely locations for contamination to be found at detectable levels.

1. Concrete floor of the building.

2. Contents of xylene storage tank.

3. Piping leading from railroad siding.

4. Piping leading into Building E5188.

5. Concrete within both pipe trenches.

6. Contents of both floor drains.

7. Soil along both concrete pipe trenches that are associated with this building.

8. Soils from below the floor of the building at the area of the floor drains.

9. Contents of the pressure equalization tank (if any).

10. Large stained area at east interior wall of building.

11. Soil along the (possible) pipeline extending west from the southwest corner of the building, including that beneath the depressed area. 


\section{References}

EAI Corporation, 1989, Historical Records Search and Site Survey of Edgewood Area Buildings, Final Report, prepared for U.S. Army Chemical Research, Development, and Engineering Center, Aberdeen Proving Ground, Maryland, under contract No. DAAIS-87-D0021.

Miller, S.F., M.D. Thompson, M.G. McGinnis, and L.D. McGinnis, 1992, Interim Progress Report/Geophysics: Building E5190 Decommissioning, Aberdeen Proving Ground, Report No. ANL/ESD/TM-33, Argonne National Laboratory, Argonne IL.

"National Historic Preservation Act," 1966, Public Law 89-665 (October 15, 1966); "National Historic Preservation Act Amendments," 1980, Public Law 96-515 (December 12, 1980).

Nemeth, G., 1989, RCRA Facility Assessment Report, Edgewood Area, Aberdeen Proving Ground, Maryland, report prepared by U.S. Army Environmental Hygiene Agency for Aberdeen Proving Ground, Maryland.

Whitman, Requardt, and Smith Engineers, 1941a, Edgewood Arsenal Benzene Storage Shed Building No. E5375, E5190, Architectural Plans, Elevations, and Section, Microfiche Number 023621, Directorate of Engineering and Housing, Aberdeen Proving Ground, Maryland (April 2, 1941).

Whitman, Requardt, and Smith Engineers, 1941b, Edgewood Arsenal Benzene Storage Building No. E5375, E5190, Architectural Plans, Elevations, and Section, Microfiche Number 023667, Directorate of Engineering and Housing, Aberdeen Proving Ground, Maryland (March 21, 1941).

Whitman, Requardt, and Smith Engineers, 1941c, Edgewood Arsenal Benzene Storage Building No. E5375, E5190, Concrete Details, Microfiche Number 023786, Directorate of Engineering and Housing, Aberdeen Proving Ground, Maryland (April 4, 1941). 


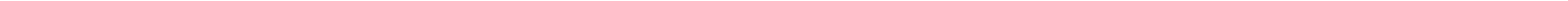




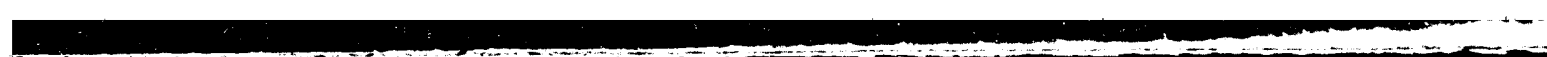

